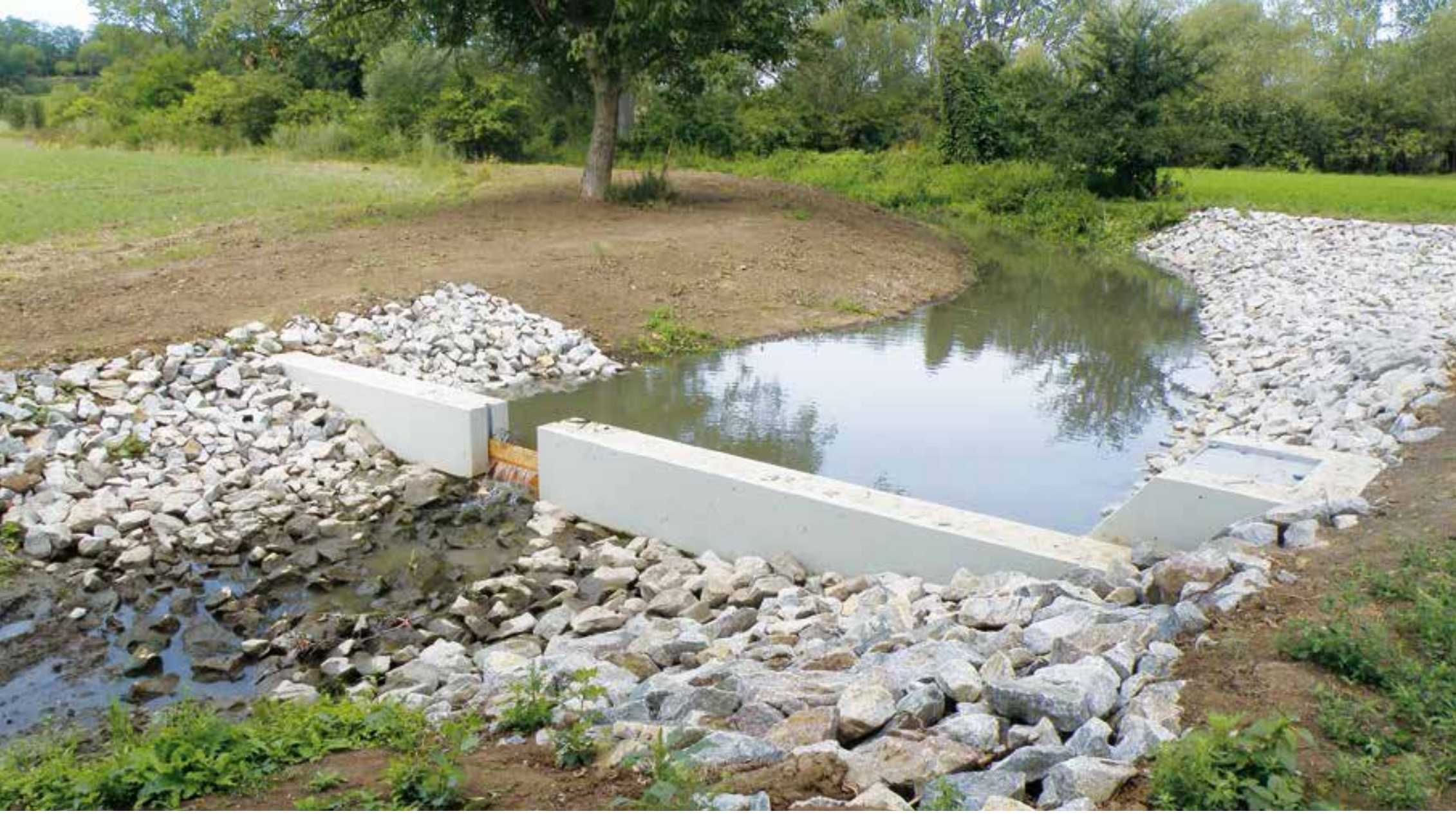

\title{
Modelování efektu prírodě blízkých opatření na hydrologickou bilanci v povodí Trkmanky
}

\section{ROMAN KOŽíN, PETR BAŠTA, VOJTĚCH MORAVEC}

Klíčová slova: prírodě blízká opatření - hydrologická bilance - retence - vodní nádrž

\section{SOUHRN}

Efekt prírodě blízkých opatření na hydrologickou bilanci byl modelován na povodí Trkmanky. Povodí se nachází na jižní Moravě a je intenzivně zemědělsky obhospodařované. $V$ rámci projektu Strategie ochrany před negativními dopady povodní a erozními jevy prírodě blízkými opatřeními v České republice (www.vodavkrajine.cz) na něm byl navržen značný počet komplexních protierozních opatření na téměř 132 km², což tvoří $43 \%$ celkové plochy povodí, viz obr. 1. Tato opatření mají za úkol minimalizovat erozi a zvyšovat celkovou retenci povodí. Cílem příspěvku je kvantifikovat vliv navržených opatření na vybrané složky hydrologické bilance pomocí modelu Bilan a následně porovnat efekt těchto opatření s efektem případné nádrže Terezín.

\section{ÚVOD}

Prírodě blízká opatření zabraňují erozi a také zvyšují celkovou retenci vody v povodí, která je jedním z klíčových faktorů utvárejících výslednou hydrologickou bilanci povodí. Celkovou retenci vody pro dané povodí tvoří časově a prostorově proměnlivé zásoby vody zadržené ve sněhové pokrývce, na povrchu vegetačního pokryvu, na povrchu povodí, v nenasycené a nasycené zóně [1]. Jedním ze způsobů jak vyhodnotit vliv změny celkové retence povodí na základě navržených či provedených opatření je aplikace modelu hydrologické bilance. Cílem príspěvku je kvantifikovat vliv všech navržených opatření ( $v$ rámci projektu Strategie ochrany před negativními dopady povodní a erozními jevy prírodě blízkými opatřeními v České republice) na vybrané složky hydrologické bilance pomocí modelu Bilan a následně porovnat efekt těchto opatření s efektem př́ipadné nádrže Terezín. Ta je jednou z 65 hájených lokalit pro akumulaci povrchových vod (LAPV) uvedených v Generelu LAPV [2]. 

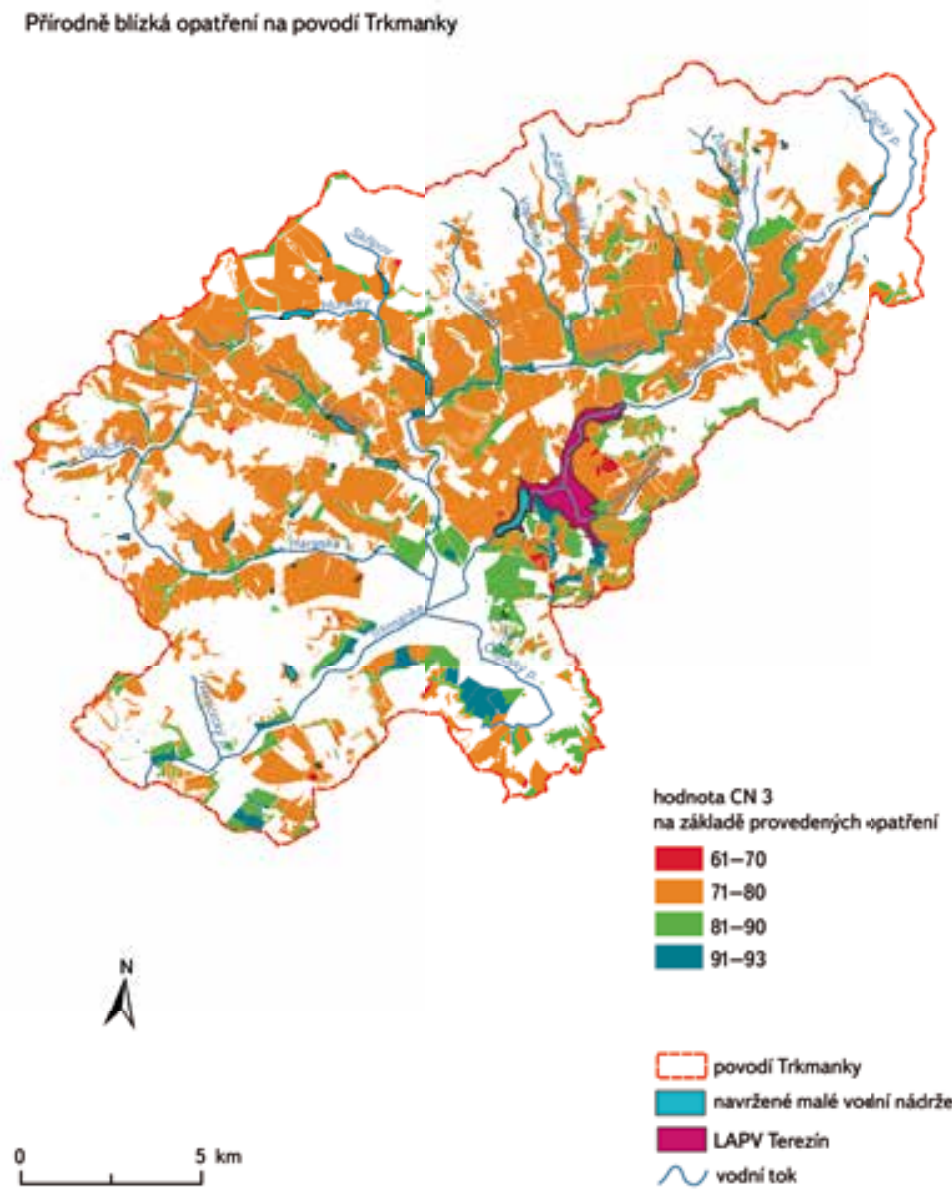

Obr. 1. Oblasti s navrženými prírodě blízkými opatřeními v povodí Trkmanky Fig. 1. Areas with proposed nature-related measures in the Trkmanka basin

\section{METODIKA}

Pro povodí Trkmanky byl kalibrován model hydrologické bilance Bilan (bilan.vuv.cz), který je dlouhodobě vyvíjen ve Výzkumném ústavu vodohospodářském T. G. Masaryka, v. v. i., dále jen VúV. Více o modelu pojednává článek viz [3]. Kalibrace modelu proběhla na základě pozorovaných srážek, teploty a průtoků v měsíčním kroku za období 1963-2010, data pocházejí z databáze Českého hydrometeorologického ústavu. Kapacita zásoby půdní vlhkosti Spa [mm] je jeden z osmi kalibrovaných parametrů a vyjadřuje schopnost půdy zadržet vodu. Když je $v$ půdním profilu zadrženo více než Spa [mm] vody,

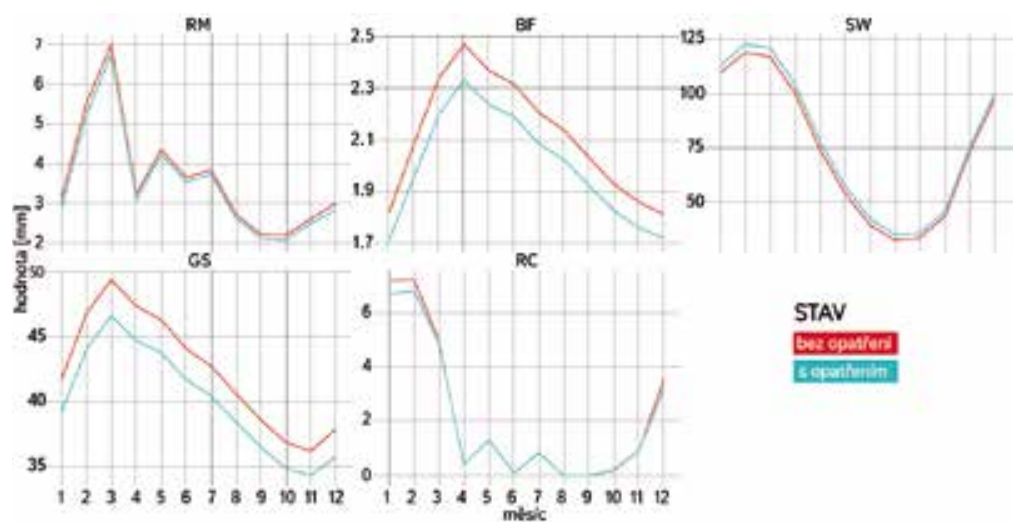

Obr. 2. Roční chod vybraných složek hydrologické bilance v povodí; červeně bez opatření, modře s opatřeními; RM - modelovaný odtok, BF - základní odtok, SW - zásoba vody v půdě, GS - zásoba podzemní vody, RC - dotace podzemní vody Fig. 2. Seasonal variation of selected variables of hydrological balance; before (red) and after (blue) proposed measures; RM - modeled runoff, BF - baseflow, SW - soil water storage, GS - ground water storage, RC - recharge of ground water

nastává průsak (perkolace) vody z půdy do horninového prostředí. Parametr Spa je možné použít jako ukazatel průměrné retenční kapacity půd v povodí. $\checkmark$ práci [1] jsou uvedeny regresní vztahy využívající geomorfologii povodí a hodnotu odtokové křivky (CN) k odhadu parametru Spa:

$$
S p a=0,71 S 3+88,91 D d-8,89 S t+65,76
$$

S3 - maximální retence pro III. typ předchozích vláhových podmínek [mm], Dd - hustota říční sítě povodí [km/ $\left./ \mathrm{km}^{2}\right]$, St - průměrný sklon říční sítě [\%].

Maximální retence vychází ze vztahu:

$$
S 3=\frac{25400-254 C N}{C N}
$$

Na základě změny hodnoty CN (navržená opatření) se přenastaví hodnota parametru Spa v modelu Bilan. Po opětovné simulaci s novou hodnotou Spa Ize kvantifikovat vliv opatření na složky hydrologické bilance. Celková hodnota CN v povodí po navržených opatření byla vypočtena váženým průměrem přes dílčí plochy.

Tabulka 1. Hodnoty vybraných veličin na povodí bez opatření a s navrženými opatřeními; CN III - hodnota pro III. typ predchozích vláhových podmínek, S3 - maximální retence pro III. typ predchozích vláhových podmínek, Spa - kapacita zásoby půdní vlhkosti, SW - zásoba vody v půdě, RM - modelovaný odtok

Table 1. Values of selected variables before and after proposed measures; CN III - curve number for the third type antecedent moisture condition (AMC), S3 - maximal retention for the third type AMC, Spa - capacity of soil moisture storage, SW - soil water content, RM - modeled runoff

\begin{tabular}{llllll} 
& CN III [-] & S3 [mm] & Spa [mm] & SW [mm] & RM [mm] \\
\hline bez opatření & 86 & 41 & 127,6 & 74,3 & 43,4 \\
\hline s opatřeními & 84 & 48 & 132,6 & 77,4 & 41,6
\end{tabular}




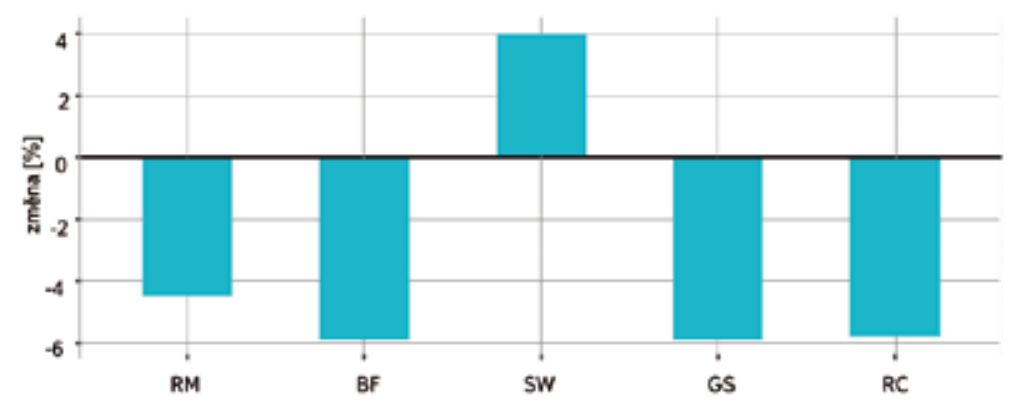

Obr. 3. Relativní změna složek hydrologické bilance po navržených opatřeních; RM modelovaný odtok, BF - základní odtok, SW - zásoba vody v půdě, GS - zásoba podzemní vody, RC - dotace podzemní vody

Fig. 3. Relative change of hydrological variables after proposed measures; RM - modeled runoff, BF - baseflow, SW - soil water storage, GS - ground water storage, RC recharge of ground water

\section{VÝSLEDKY A DISKUSE}

Kapacita zásoby půdní vlhkosti (Spa) se s navrženými opatřeními zvy̌ší o 5 mm a zásoba vody $v$ půdě (SW) $\circ 3 \mathrm{~mm}$. $V$ důsledku toho poklesne celkový odtok (RM) z povodí o $2 \mathrm{~mm}$. Výsledky modelování hydrologické bilance za období 1963-2010 shrnuje tabulka 1. Zvětšením retence se podaři v povodí zadržet ročně v průměru o $943950 \mathrm{~m}^{3}$ vody více. Toto relativně malé číslo (vzhledem k rozsahu navržených opatření) je dáno především nízkým průměrným ročním úhrnem srážek 540 mm a relativně vysokým územním výparem 498 mm. Na povodí s vyšší průměrnou srážkou by bylo množství zadržené vody zcela určitě vyšší. Na druhou stranu, pokud výslednou hodnotu prevedeme na průtok, dostaneme $30 \mathrm{l} / \mathrm{s}$, což vzhledem k minimálnímu zůstatkovému průtoku (MZP) $95 \mathrm{I} / \mathrm{s}$ není zanedbatelné. MZP byl vypočten podle vzorce $M Z P=0,73 * Q_{10}$ $\left(Q_{10}-10 \%\right.$ kvantil z řady měsíčních průtoků) a odpovídá MZP na základě nové metodiky uvedené $v$ [4].

Tabulku 1 doplňují grafy na obr. 2 a 3. Roční chod vybraných složek hydrologické bilance se $v$ podstatě nemění. $V$ důsledku navržených opatření dochází ke zvětšení zásoby vody v půdě (SW), ostatní složky hydrologické bilance vykazují pokles. Je zajímavé, že v tomto konkrétním prípadě dochází ke snížení dotace podzemních vod v zimních měsících a tím i k poklesu zásob podzemní vody. To pravděpodobně souvisí s tím, že více vody se udrží v pưdě, a ta je následně využita rostlinami ve vegetačním období.

Deficitní objemy byly počitány na základě prahového prưtoku, který byl dán MZP vypočteným podle vzorce $M Z P=0,73 * Q_{10}\left(Q_{10}-10 \%\right.$ kvantil z řady měsić ních průtoků), který odpovídá MZP na základě nové metodiky uvedené v [4]. K výpočtům byly použity měsíční průtoky za období 1963-2010. Analýza deficitních objemů ukázala, že se po navržených opatřeních zvýšila četnost, velikost i doba trvání deficitních objemů, viz obr. 4 a 5. Průměrná hodnota deficitu se nezměnila, naopak průměrná délka deficitního období lehce klesla. Z hlediska množství vody ve vodních tocích se tedy provedená opatření projevují spíše negativně. Pokles množství vody ve vodoteči je na úkor zvýšeného množství vody zadrženého v pưdě, tj. zlepšení podmínek pro vegetaci.

$\checkmark$ povodí Trkmanky se také nalézá LAPV Terezín s celkovým potenciálním objemem 5,6 mil. $\mathrm{m}^{3}$ a zatopenou plochou 316 ha. Pro tuto nádrž můžeme očekávat nadlepšený průtok $149 \mathrm{I} / \mathrm{s}$ S 95\% zabezpečeností, což odpovídá ročně v průměru 4,7 mil. $\mathrm{m}^{3}$ vody. Výsledky pocházejí z projektu Možnosti kompenzace negativních dopadů klimatické změny na zásobování vodou a ekosystémy využitím lokalit vhodných pro akumulaci povrchových vod, viz www.lapv.vuv.cz. Pro výpočet byl použit model WATERES (github.com/tgmwri/wateres), který je

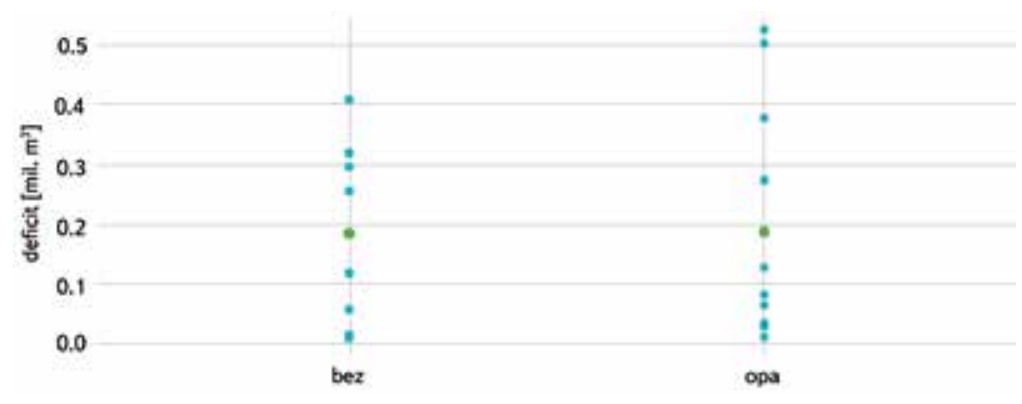

Obr. 4. Hodnoty deficitních objemů - bez (bez) a s (opa) navrženými opatřeními; zeleně zobrazen průměr

Fig. 4. Deficit volumes in the basin before (bez) and after (opa) measures; green dots represent mean

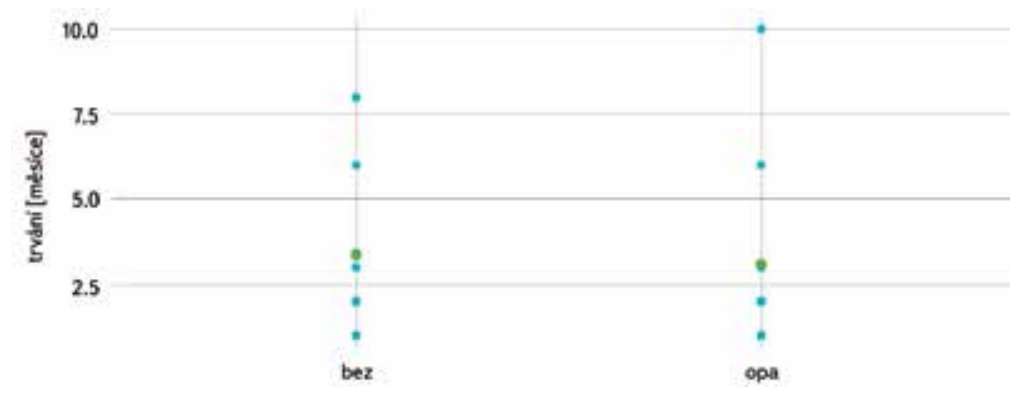

Obr. 5. Délka trvání deficitních událostí - bez opatření (bez) a s navrženými opatřeními (opa); zeleně zobrazen průměr

Fig. 5. Duration of drought event - before measures (bez) and after proposed measures (opa); green dots represent mean

vyvíjen v rámci projektu. MZP pod nádrží je vypočten podle [3] $48 \mathrm{I} / \mathrm{s}$, tedy $\checkmark$ obdobích sucha by ještě zbývalo $100 \mathrm{l} / \mathrm{s}$, např. pro závlahy, což je v průměru 3krát více, než mohou poskytnout navržená prírodě blízká opatření.

\section{ZÁVĚR}

V předloženém článku je navržen možný postup kvantifikace vlivu prírodě blízkých opatření na složky hydrologické bilance. Bylo zjištěno, že na povodí Trkmanky by navržená opatření, provedená na $43 \%$ celkové plochy povodí, pomohla zadržet v průměru za rok o $943950 \mathrm{~m}^{3}$ více vody v půdě. Zvýšení celkové retence je ale na úkor celkového odtoku z povodí a pravděpodobně by se zvýšila četnost, velikost a trvání deficitních objemů. Na povodích tohoto typu, kde se vyskytuje nízký úhrn srážek a poměrně vysoký výpar, se jeví smysluplnější dělat přírodě blízká opatření za účelem snižování eroze a zlepšení kvality půdy než za účelem zvyšování celkové retence. $V$ prípadě postavení nádrže Terezín Ize dodávat v suchých obdobích až 100 I/s (MZP je cca 50 l/s), což je v přepočtu $3153600 \mathrm{~m}^{3}$ za rok.

Nádrž v intenzivně obhospodařovaném povodí se ovšem neobejde bez rozsáhlých protierozních opatření a změny agrotechnických postupů v jejím povodí, které redukují odnos půdy a její akumulaci v nádrži, což by mělo za následek zanášení a zmenšení akumulačního prostoru.

\section{Poděkování}

Studie byla provedena v rámci úkolu Činnosti k podpoře výkonu státní správy v problematice sucho $v$ roce 2016. 


\section{Literatura}

[1] MÁCA, P. a kol. Využití geomorfologických charakteristik pro odhad celkové retence $v$ povodí. Vodohospodáršsé technicko-ekonomické informace, 2016, roč. 58, č. 6, s. 54-57.

[2] MZE a MŽP. Generel území chráněných pro akumulaci povrchových vod a základní zásady využití těchto území. Ministerstvo zemědělství a Ministerstvo životního prostředí, 2011.

[3] VIZINA, A. a kol. Nové možnosti modelu BILAN. VTEI, 2015, roč. 57, Č. 4-5. ISSN 0322-8916.

[4] BALVÍN, P. a kol. Stanovení minimálních zůstatkových průtoků v České republice, konference Rybníky 2016.

\section{Autoři}

Ing. Roman Kožín ${ }^{1,2}$

凶roman.kozin@vuv.cz

Ing. Petr Bašta ${ }^{2}$

凶bastap@fzp.czu.cz

Ing. Vojtěch Moravec ${ }^{2}$

凶vmoravec@fzp.czu.cz

'Výzkumný ústav vodohospodářský T. G. Masaryka, v. v. i.

${ }^{2}$ Fakulta životního prostředí, Česká zemědělská univerzita

Příspěvek prošel lektorským řízením

\section{MODELING THE EFFECT OF NATURE- RELATED MEASURES ON THE WATER BALANCE IN THE TRKMANKA BASIN}

\section{KOZIN, R. ${ }^{1,2}$; BASTA, P. ${ }^{2}$; MORAVEC, V. ${ }^{2}$}

'TGM Water Research Institute, p. r. i.

${ }^{2}$ Faculty of Environmental Sciences, Czech University of Life Sciences in Prague

Keywords: nature-related measures - water balance retention - water reservoir

The effect of nature-related measures on the water balance was modeled in the Trkmanka basin. The basin is located in the Moravia, south-east region of the Czech Republic. The area is intensively farmed and under the project "Strategy for protection against the negative impacts of floods and erosion phenomena by nature-related measures in the Czech Republic" (www.vodavkrajine.cz) a large number of complex erosion control measures of almost $132 \mathrm{~km}^{2}$ were proposed, representing $43 \%$ of the total catchment area (Fig. 1). These measures are intended to reduce soil erosion and to increase the overall retention of the river basins. The aim of the paper is to quantify the impact of the proposed measures on the selected components of the water balance using the BILAN model. Then compare the effect of these measures with the potential Terezín reservoir. 